\title{
PURIFICATION OF \\ DD-CARBOXYPEPTIDASES FROM \\ STREPTOMYCES STRAINS R61 AND K15 \\ BY ANTIGEN-ANTIBODY AFFINITY \\ CHROMATOGRAPHY
}

\author{
A. Marquet, M. Nguyen-Distèche, M. Leyh-Bouille and \\ J. M. Ghuysen \\ Service de Microbiologie, Faculté de Médicine, Université de Lìge, Institut de \\ Botanique, 4000 Sant Tilman, Liège, Belgium
}

\section{ABSTRACT}

The exocellular R61 DD-carboxypeptidase and the lysozyme-releasable K 15 DD-carboxypeptidase were purified using anti-exocellular R61 enzyme IgG-Sepharose as immunoadsorbent. The specific activity of R61 enzyme was increased 70 fold (yield $90 \%$ ) and that of K15 enzyme was increased 550 fold (yield $50 \%$ of the adsorbed material).

\section{INTRODUCTION}

The cellular enzyme system involved in peptide crosslinking during synthesis of the bacterial cell wall peptidoglycan consists of at least 1) a transpeptidase activity which catalyzes peptide bond formation, a reaction through which the carboxyl group of the penultimate D-Ala residue of a peptide donor ending in D-Ala-D-Ala is transferred to the free w-amino group of another peptide acceptor, and 2) a DD-carboxypeptidase activity which simply hydrolyzes the C-terminal D-Ala-D-Ala sequences of the peptide donors without performing any transfer reaction. Both activities are sensitive to B-lactams, but the inhibition of either of them may be the cause for cell lysis depending on the species investigated.

The DD-carboxypeptidase-transpeptidase enzyme system in Streptomyces sp. is relatively well known (1). In strains $K 15$ und $R 61$, it consists of: 1) a membrane-bound transpeptidase capable of performing low DD-carboxypeptidase activity and 2) a set of DD-carboxypeptidases: a) membrane-bound, b) lysozyme-releasable and c) exocellular, having low transpeptidase activity (2). Thp relationship between the exocellular, lysozyme-releasable and membrane-bound DD-carboxypeptidasetranspeptidase enzyme system remains to be determined.

The exocellular DD-carboxypeptidase can be isolated from the culture filtrates. At present, the enzyme excreted by strain R61 is the only one which has been purified to homogeneity (3). The procedure makes use of conventional techniques, it is lengthy and the final yield is sma11.

The lysozyme-releasable DD-carboxypeptidase can be released from the cel1s through the enzymatic transformation of the mycelium into protoplasts by lysozyme in a sucrose medium (2). This enzyme represents a very small proportion of the total protein present in the 
original cell extracts and therefore its isolation is not easy. Previous studies have shown that the purified exocellular DD-carboxypeptidase of strain $R 61$ and the lysozyme-releasable DD-carboxypeptidase of this and other Streptomyces strains were immunologically related (4). On this basis, the purification of the lysozymereleasable enzyme of strain $K 15$ and of the exocellular $R 61$ enzyme was attempted by affinity chromatography using the Igf fraction of an anti-RG1 enzyme antiserum as ligand.

\section{PURIFICATION OF THE. I gG FRACTION}

The antibodies directed against 261 exocellular DD-carboxypeptidase were purified by affinity chromatography using 261 enzyme Sepharose $6 B$ as adsorbent. The sepharose was activated according to sundberg and Porath (5). Bisoxyran- rather than CNBr-activated Sepharose was used because very alkaline conditions were required to dissociate the antigen-antibody complex.

Epoxy-activated Sepharose (2 g - 900-1000 vequiv, of epoxide groups/ $\mathrm{g}$ sry gel) was added to a solution ( $1 \mathrm{~mL}$ ) of the R61 exocellular cnzyme ( $18 \mathrm{mg}$; i.e. 0.5 umol of purified enzyme) in $0.5 \mathrm{M}$ carbonate buffer pli 9.5 and the suspension was stirred by rotation for 72 hrs at $28^{\circ} \mathrm{C}$. Under these conditions about $30 \%$ of the enzyme was bound to the support. The enzyme-Sepharose complex was successively washed with 1) $250 \mathrm{ml} 0.5 \mathrm{M}$ carbonate pll 9.5 - 0.5 M NaCl; 2) $250 \mathrm{ml} 0.1 \mathrm{M}$ glycine.HCl pH 3.0-0.5 M NaCl; 3) 1120 ; 4) $250 \mathrm{ml} 30 \mathrm{mM}$ Tris. HCl pH $7.5-0.5 \mathrm{M} \mathrm{NaCl}$ and $20 \mathrm{mM} \mathrm{CaCl}{ }_{2}$ The remaining free epoxide

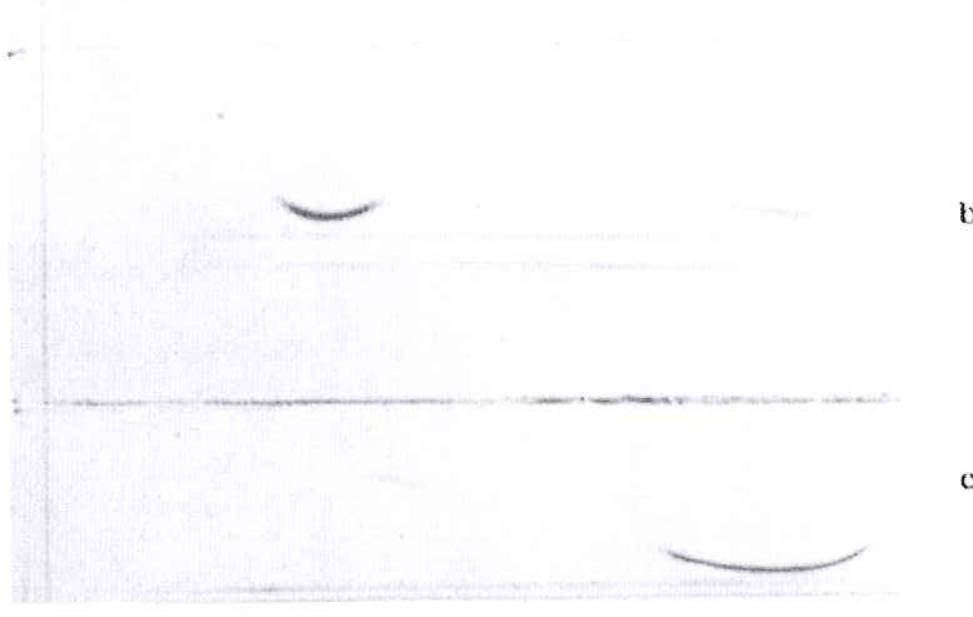

Fig. 1. Immunoelectrophoresis of a) complete exocellular R61 antiserum, b) $0.5 \mathrm{M} \mathrm{NaCl}$ eluted material and c) $0.2 \mathrm{~N}$ carbonate buffer pll 11.4 eluted IgGs from R61 enzyme Sepharose adsorbent, tested against antiserum to complete rabbit serum. 
groups were blocked by reaction with $2 \mathrm{M}$ ethanolamine at pll 9.5 for 8 hrs at $25^{\circ} \mathrm{C}$. This adsorbent was washed and finally equilibrated with $10 \mathrm{mM}$ Tris.HCl pll 7.7. $2 \mathrm{ml}$ of complete anti-R61 enzyme antiserum were adsorbed onto a colum of the above mentioned adsorbent ( $1 \mathrm{mg}$ of $1 \mathrm{igand} / \mathrm{ml}$ of gel). The non-adsorbed material had completely lost the capability of inhibiting the DD-carboxypeptidase activity of the 1261 exocellular enzyme, which showed that fixation of the specific IgGs had occurred with high efficiency. The column was thoroughly washed with $0.5 \mathrm{M} \mathrm{NaCl}+0.01 \mathrm{MT}$ Tis.llCl pH 7.7. The IgGis were eluted from the adsorbent with $0.2 \mathrm{M}$ carbonate buffer pll 11.4, rapidly dialysed against $10 \mathrm{mM}$ Tris. $11 \mathrm{C} 1$ buffer pH 7.7 and concentrated to $2 \mathrm{ml}$ by ultrafiltration. Through a series of several runs performed under identical conditions, $30 \mathrm{mg}$ of purified $1 \mathrm{~g}(\mathrm{\prime}$ 's (Fig. 1) were obtained and used as ligand for the purification of the lysozyme-releasable enzyme.

\section{ENZYME PURIFICATION}

Sepharose $6 \mathrm{~B}$ was activated as described above and the purified IgG fraction was coupled onto it. The reaction was performed in $0.5 \mathrm{M}$ carbonate buffer pll 10.5 for 48 hrs at $34^{\circ} \mathrm{C}$. In this step the yield was $84 \%$. The IgG-Sepharose 6B, washed and treated with ethanolamine as described above, was equilibrated with $30 \mathrm{mM}$ Tris.llCl pll 7.5 .

In order to check the behaviour of the immunoadsorbent, the purification of the crude exocellular 261 enzyme was first attempted. The enzyme was applied to the column, eluted with $0.2 \mathrm{~N}$ carbonate buffer pH 11.4, dialysed immediately against $10 \mathrm{mM}$ Tris.llC 1 pll 7.7 and concentrated by ultrafiltration. Measurements of enzyme activity showed a 70 fold increase in specific activity. The yield was $90 \%$ (Table 1).

TABLE 1. Purification of exocellular R61 DD-carboxypeptidase on anti-exocellular R61 DD-carboxypeptidase $1 \mathrm{gG}-\mathrm{Sepharose} 6 \mathrm{~B}$ immunoadsorbent.

\begin{tabular}{|c|c|c|c|}
\hline & $\begin{array}{l}\text { Total activity" } \\
(\mu \operatorname{mol} \text { os/min) }\end{array}$ & Yield & $\begin{array}{l}\text { Specific activity"* } \\
(\mu-\operatorname{moles} / \mathrm{min} / \mathrm{mg})\end{array}$ \\
\hline Crude enzyme & 1790 & 100 & 0.74 \\
\hline $\begin{array}{l}\text { Non-adsorbed } \\
\text { material }\end{array}$ & 0 & 0 & \\
\hline $\begin{array}{l}\text { NaCl } 0.5 \mathrm{M} \text { pll } 7.9 \\
\text { eluted material }\end{array}$ & 0 & 0 & \\
\hline $\begin{array}{l}\mathrm{Na}_{2} \mathrm{CO}_{3} \mathrm{O} .2 \mathrm{M} \text { pll } 11.4 \\
\text { eluted material }\end{array}$ & 1658 & 92 & 52 \\
\hline
\end{tabular}

- Substrate: $1.6 \mathrm{mM} \mathrm{Ac} 2^{-L-L y s-D-A l a-D-A l a ~}$

- Specific activity measured at substrate concentrations of 10 times the Km value (12 mM) as described by J.M. Frère et al. (3).

The same technique was then applied to a crude lysozyme-releasable DD-carboxypeptidase preparation of Stroptomyces K15, obtained after ammonium sulphate precipitation. The K15 enzyme was adsorbed on the IgG-Sepharose colum, which was then washed with $0.5 \mathrm{M} \mathrm{NaCl,} 0.2 \mathrm{M}$ carbonate buffer H 10.5. The enzyme was eluted with 0.2 M carbonate pH 11.4, resulting in a 550 fold increase in specific activity with 
a yicld of $50 \%$ of the adsorbed material (Table 2 ).

TABLE 2, Purification of K15 lysozyme-releasable DD-carboxypeptidase on anti-exocellular R61 DD-carboxypeptidase IgG-sepharose $6 B$ i mmunoadsorbent.

\begin{tabular}{|c|c|c|c|}
\hline & $\begin{array}{l}\text { Total activity" } \\
((\mathrm{moles} / \mathrm{min})\end{array}$ & Xield & $\begin{array}{l}\text { Specific activity } \\
(\text { ( molcs } / \mathrm{min} / \mathrm{mg})\end{array}$ \\
\hline Crude cnzyme & 0.255 & 100 & 0.002 \\
\hline $\begin{array}{l}\text { Non-adsorbed } \\
\text { material }\end{array}$ & 0.139 & 55 & \\
\hline $\begin{array}{l}\mathrm{NaCl} 0.5 \mathrm{M} \text { pll } 10.5 \\
\text { eluted matcrial }\end{array}$ & 0.145 & 57 & \\
\hline $\begin{array}{l}\mathrm{Na}_{2} \mathrm{CO}_{3} 0.2 \mathrm{M} \text { pll } 11.4 \\
\text { eluted material }\end{array}$ & 0.060 & 23.5 & 1.15 \\
\hline
\end{tabular}

- Substrate: $1.6 \mathrm{mM} \mathrm{Ac},-\mathrm{L}-\mathrm{Lys}-\mathrm{D}-\mathrm{Ala}-\mathrm{D}-\mathrm{Al}$ la

* Specific activity measured at substrate concentration of 10 times the $\mathrm{Km}$ value (9 $\mathrm{mM})$ as described by $\mathrm{M}$. Leyh-Bouille et al. (2).

\section{CONCLUSION}

The anti-exocellular R61 enzyme antiserum was found to inhibit the DD-carboxypeptidase activity of the exocellular and lysozyme-releasable enzymes from other streptomyces strains (4). On this basis, the exocellular R61 DD.carboxypeptidase and lysozyme-releasable K15 DD-carboxypeptidase were purified by using anti-exocellular R61 enmyme IgG-sepharose $6 B$ as an immunoadsorbent. The results reported here are still preliminary. However, they arc very promising and when the tcchnique will be refincd, it may well give risc to procedures through which the various cnkymes of the streptomyces peptidoglycan crosslinking enzyme system can be isolated in a specific manner, with high yiclds and with a minimum of steps involved.

\section{REFERENCES}

(1) J.M. Ghuysen, The concept of the penicillin target from 1965 until today, J. Gen. Microbiol. 101, 13-33 (1977).

(2) M. Leyh-Bouille, J. Dusart, M. Nguyen-Distèche, J.M. Ghuysen, P.k. Reynolds and H.R. Perkins, The peptidoglycan crosslinking enzyme system in streptomyces strains R61, K15 and rimosus. Exocellular, lysozyme-releasable and membrane-bound, Eur. J. Biochem., in press (1977).

(3) J.M. Frère, J.M. Ghuysen, H.R. Perkins and M. Nicto, Molecular weight and amino acid composition of the exocellular DD-carm boxypeptidase-transpeptidase of Streptomyces R61, Biochem. J. $135,463-468(1973)$.

(4) M. Nguycn-Distèche, J.M. Frère, J. Dusart, M. Leyh-Bouille, J.M. Ghuysen, J.J. Pollock and U.J. Iacono, The peptidoglycan crosslinking enzyme system in streptomyces R61, K15 and rimosus. Immunological studies. Eur.J.Biochem., in press (1977) 
(5) L. Sundberg and J. Porath, preparation of adsorbents for biospecific affinity chromatography. Attachment of group-containing ligands to insoluble polymers by means of bifunctional oxiranes, J. Chromat. $90,87-98(1974)$.

\section{ACKNOWLEDGEMENTS}

The work was supported in part by the Fonds de la Recherche

Fondamentale Collective, Brusse1s, Belgium, the National Institutes of Health, Washington, D.C. (contract No 1 RO1 AI $13364-01 \mathrm{MBC}$ ) and by by an EMBO fellowship to A. Marquet. We also thank UCB, Brussels, Belgium, for financial support. M.N.D. is Charge de recherches of the Fonds National de la Recherche Scientifique, Brusse1s, Belgium. 